\title{
A Preliminary Account of the Production of Annual Rings in the Scales of Plaice and Flounders.
}

\author{
By \\ D. Ward Cutler, M.A. \\ Assistant Lecturer in Zoology, University, Manchester.
}

With Figures 1-10 in the Text, and Tables I to VI at the end.

IT is only within comparatively recent times that it has been proved that the otoliths and scales of certain Teleostean fish can be used for the determination of their age.

Rings of growth, as they are called, are produced on these structures, and it is by counting the number that the age is ascertained, in much the same way as the approximate age of a tree may be determined by counting the annual rings.

In May, 1915, I was appointed as a temporary assistant naturalist to the Marine Biological Association at Plymouth, and at the suggestion of Dr. Allen decided to devote my time to an investigation of the otoliths and scales of Flounders and Plaice. My work on the otoliths I hope to publish at a future date.

It has often been asserted that the scales of these fish are of little or no value as age determiners. Thus Cunningham in 1905 stated that though summer and winter lines of growth are visible, yet "in most cases the zones are somewhat difficult to distinguish, and it would be by no means easy to form a confident judgment of the age of the fish by examination of the scales alone. The conclusion drawn from the scales must be confirmed or tested by examination of the otolith."

This preliminary account of my work is divided into two parts : in the first I hope to show that it is possible to ascertain the age of Flounders and Plaice by an examination of their scales, just as accurately as by the otoliths, in fact that the otolith growth rings and those found on the scales give identical results.*

* The annual rings on the otoliths of Flounders are not so distinct as those of the Plaice, indeed Wallace and other workers on otoliths hold that age determination is uncertain from Flounder otoliths. The scales which I have examined from these fish exhibit maxima and minima as regularly and distinctly as do those of the Plaice. 
The second part will deal with experiments which were performed with a view to solving the problem of what are the conditions necessary to the production of these annual rings.

\section{PART I.}

\section{METHODS.}

A very few observations were sufficient to convince me that it was impossible to detect with any certainty rings on the scales of either Flounders or Plaice by the ordinary methods of examination. The sclerites, that is the thickened cells covering the scale, were apparently of such a uniform width that it was almost impossible to differentiate between the wide ones formed in the summer and the narrow winter ones.

In 1915 Winge published a paper on the scales of the cod, and described a new method which he had employed for his investigation.

His method was as follows: "A microscope stand with mechanical stage and ocular micrometer, and an objective having a focal diameter of about $8 \mathrm{~mm}$. form the best combination. . . . One or more scalesfresh scales are especially suitable on account of their transparency-are placed on the object glass, their longitudinal axis about parallel with the longitudinal direction of the object glass itself. The micrometer is turned so as to fall parallel with the scales. . . . In order to obtain a curve for one of the scales the instrument is focussed to the centre of the one selected, and all sclerites in the longest radius of the scales then measured. ... In order to provide a survey of the values thus obtained, the units are noted down on square-ruled paper. A horizontal axis is drawn, from which the measurements of the calcareous plates are marked off in a perpendicular direction, one by one, against each perpendicular line on the paper. On joining up the points thus obtained by straight lines, a curve is produced, which gives a distinct view of the variations in the breadth of the sclerite rings from the centre of the scale towards its periphery. Where the curve is low, the sclerites have been small, where it lies high, they have been large. A glance at the horizontal axis will show how many sclerites in all the scale contains, as also the number situate between each minimum, and the next. The growth rings are thus shown graphically as an alternation of maxima and minima."

The method given above is broadly the one which I employed in my investigations. The scales were examined in fresh water. The proportional width of successive sclerites is obviously the important factor to determine, thus making the absolute width of each sclerite of little importance. I used the distance between two degrees marked on the micrometer as the unit, each division being $10 \mu$. 
The values so obtained were then plotted on squared paper as described above, ten units of the paper in a vertical direction, representing one division of the micrometer; thus fractions of a unit are easily plotted. By this method small differences in the widths of successive sclerites

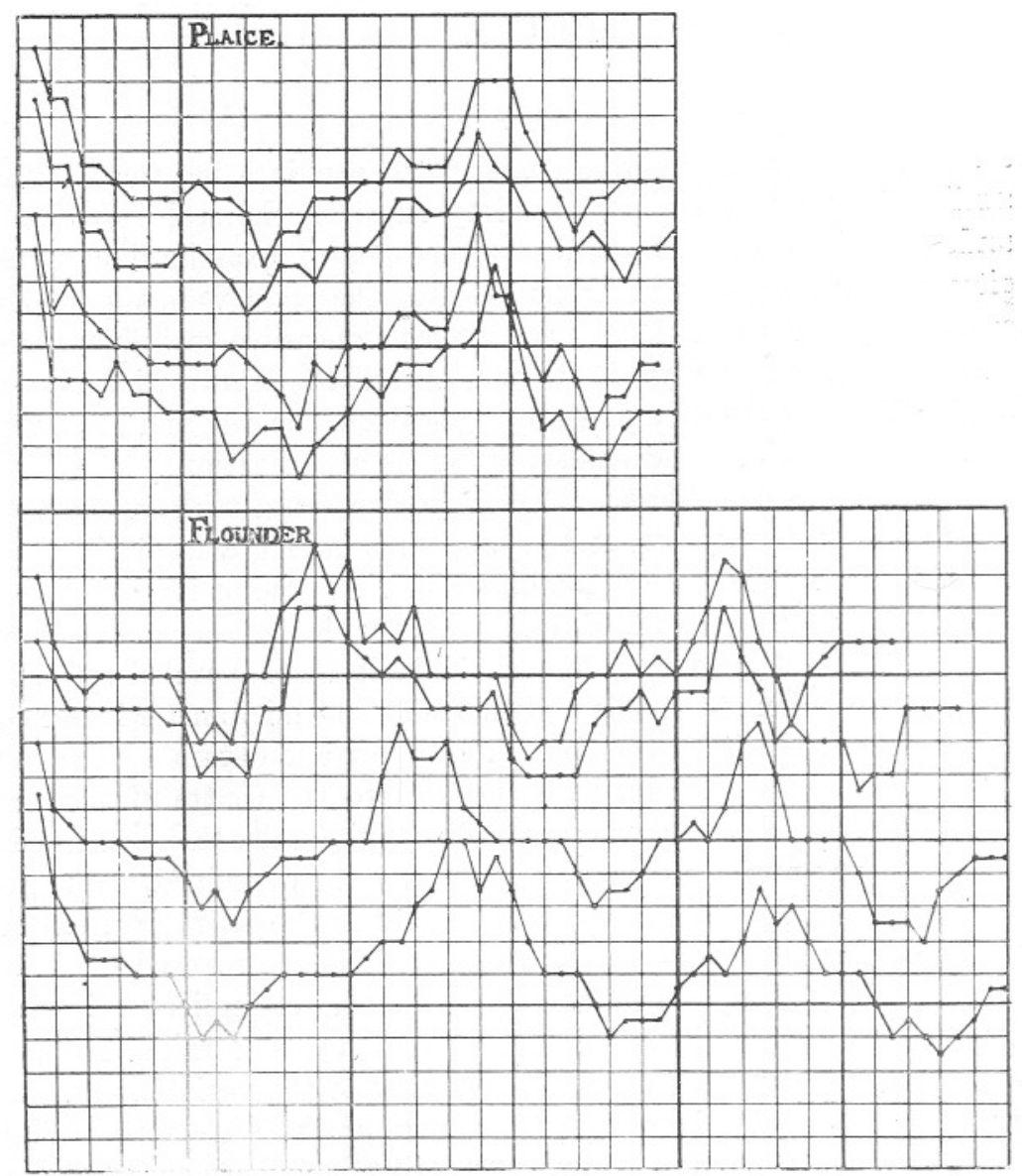

FrG. 1.-Scale curves from two fish, a Plaice and a Flounder. Four curves are drawn for each fish. Note the great resemblance between the four scale curves of each series.

are easily detected, and by it I found that growth rings on Plaice and Flounder scales are as distinctly shown as in the scales of other fishes.

\section{SCALE INVESTIGATIONS.}

The total number of fish examined was 137 , of which 85 were Flounders and 52 Plaice. In order to determine if there were any marked 


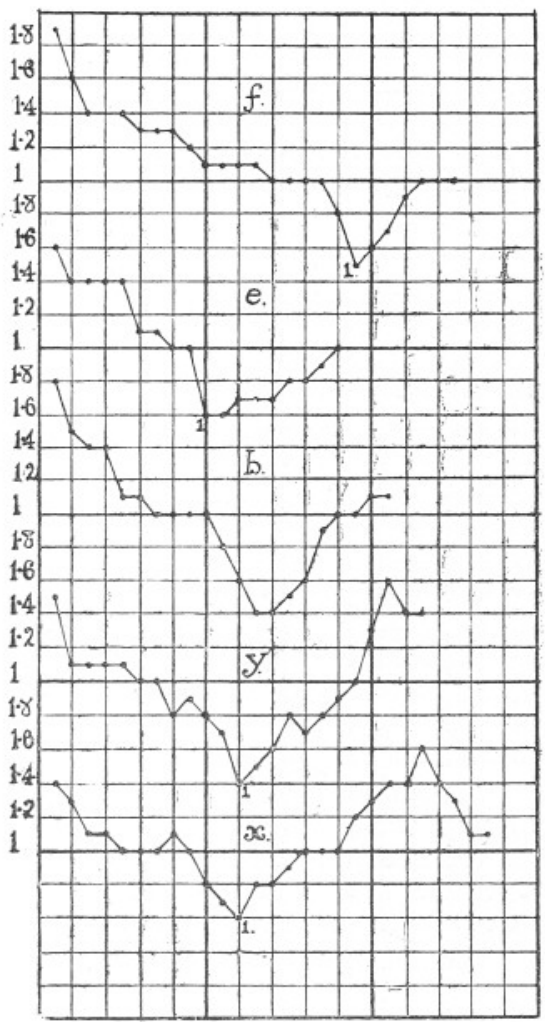

FIG. 2.-Scale curves of one year old fish. The letters refer to Table I.: the figures indicate the first winter's growth.

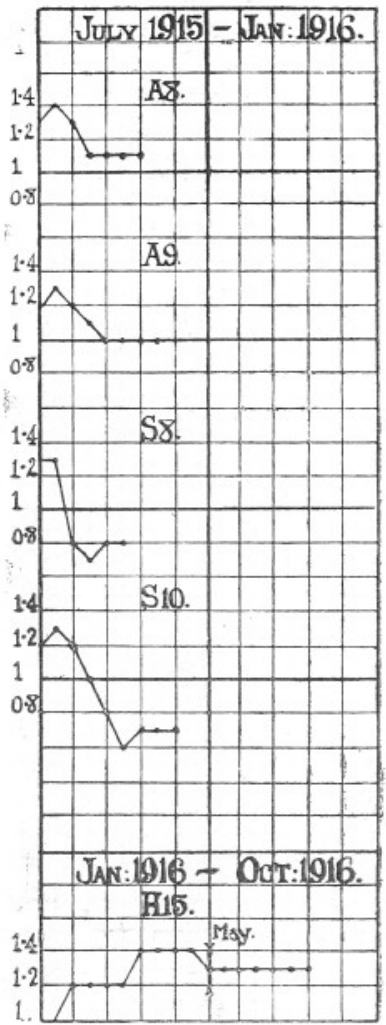

FIG. 10.-Partial curves of scales from fish in bad condition.

$A=$ abundant tank.

$\mathrm{S}=$ scanty $\operatorname{tank}$.

$\mathrm{H}=$ hot tank.

The numbers indicate the fish in the corresponding tables.

IN FIGURES 2 TO 10 THE DOTS ON THE CURVES REPRESENT THE WIDTHS OF THE SCLERITES OF THE SCALE. THESE ARBITRARY WIDTHS ARE GIVEN AT THE SIDE OF EACH CURVE.

IN FIgURES $5,6,7,8,9$ THE FIRST DOT ON THE CURVES INDICATES THE WIDTH OF THE LAST SCLERITE ON THE SCALE BEFORE THE FISH WAS EXPERIMENTED UPON; THE SECOND DOT INDICATES THE WIDTH OF THE FIRST SCLERITE PRODUCED UNDER ARTIFICIAL CONDITIONS.

IN EACH FIGURE THE LINE DIVIDING A CURVE INTO TWO PARTS IS THE LINE OF DEMARCATION BETWEEN TWO PERIODS OF THE EXPERIMENT. 
variation between scales taken from different parts of the body, four scales from various regions were examined in 45 cases. It will be seen by reference to Fig. 1 that, apart from minor variations, the scales from the

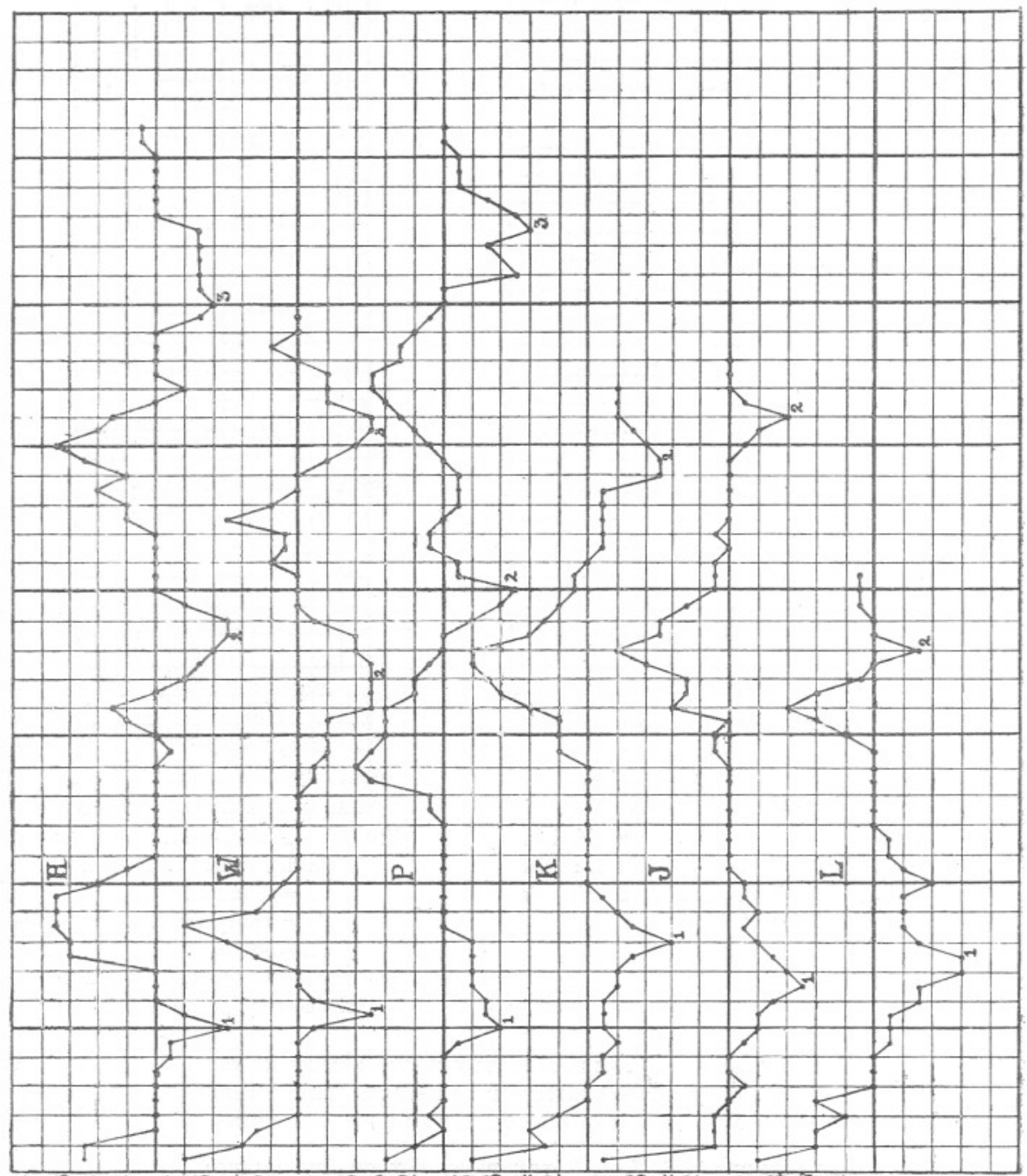

6.

FIG. 3.-Scale curves from 2 and 3 year old fish. The letters indicate the same scales in Table I. ; the numbers the successive winter zones.

same fish are very constant. The personal error was eliminated as far as possible by measuring these scales on different days, no reference being made to any previous measurements before the whole series had been completed. 

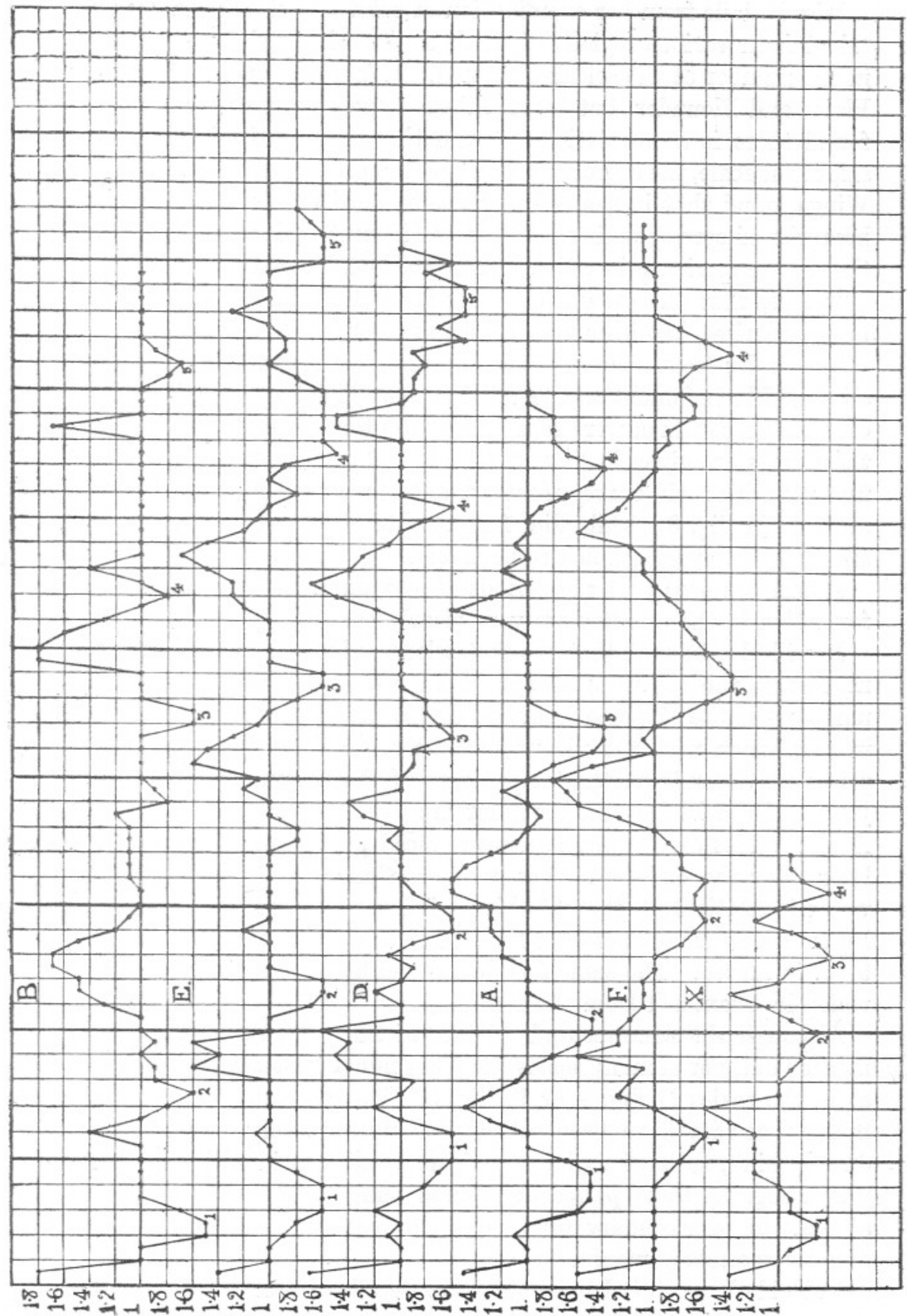

FIG. 4.-Curves from the sclerites of 4 and 5 year old fish. The letters refer to those given in Table I ; the numbers indicate the succesive winter zones of growth. 
Miss Esdaile from her examination of salmon scales found that those taken from various regions of the body invariably show great changes in the number of the sclerites formed. This undoubtedly occurs in the Plaice and Flounder, but by no means to the same extent; when it is found there is a correlation between the number of sclerites and the size of the scale, the longest scale having the greatest number of sclerites. Winge found that in the cod there were considerable variations in the breadths of corresponding sclerites of different scales. I have not had the same experience in either Plaice or Flounder scales. It is obvious, therefore, that the growth of a big scale does not consist in making broad sclerites, but in increasing the number.

The scales from fishes of different ages have been examined, and in all cases I have found that the growth rings which they exhibit are identical with those which were seen on the otoliths. Scale curves exhibiting these rings are given in Figs. 2, 3 and 4. Fig. 2 shows curves from five first year fish : six curves from two and three year old fish respectively are seen in Fig. 3: while Fig. 4 represents six curves from three four and three five year old fish respectively.

It will be noted that the periods of maximum and minimum breadth formation in the sclerites are very clearly shown.

It will also be seen that the first sclerite of the scale, that is the one nearest to the centre is always broad, the succeeding ones becoming narrower as the distance from the centre increases. This is of interest in connection with the view that I hold, that the width of the scale primarily depends on the temperature of the surrounding water. The young of the Plaice and Flounder are usually born about the end of April : scales are, however, not produced until a month or six weeks later, thus the scale growth is not begun until the temperature of the water is relatively high. At this period the temperature of the sea at Plymouth is usually between $13^{\circ}$ and $13.5^{\circ} \mathrm{C}$., as compared with about $9^{\circ} \mathrm{C}$. in March. The same fact was noted by Winge for the cod scales which he examined from the Faroes.

Although the maxima and minima of the curves are quite sharply marked out, yet in many scales one notes minor depressions or elevations as in the scales D Fig. 4 or H Fig. 3. These secondary maxima and minima, as they have been called by Winge, are very common and are due, I think, to local variations of the conditions in which the animal was living. A short period of lowered temperature being sufficient to account for a secondary minimum: the converse conditions bringing about a secondary maximum.

In Table I. (p. 491) I have given the details of some of the fish which I have examined. The first column gives the age as determined by the otolith, the second the length as measured from the tip of the snout to the 


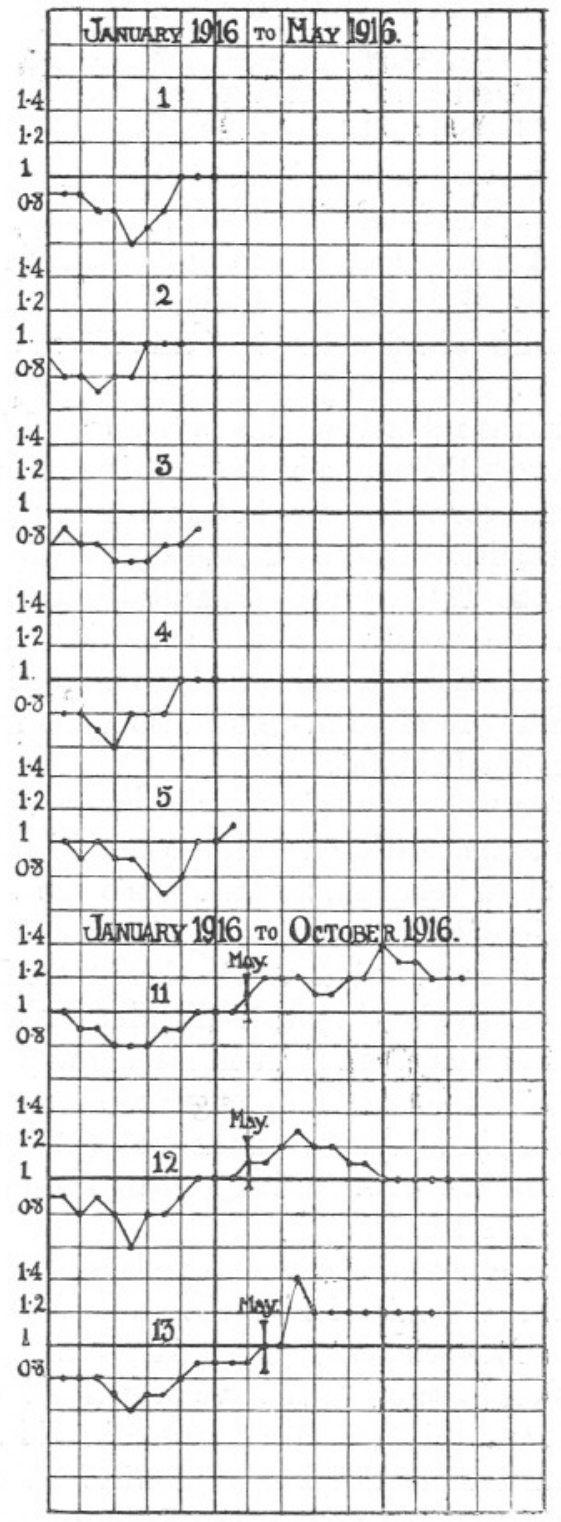

FIc. 5.-Partial curves of scales from control fish. The number over each scale curve indicates the corresponding scale in Table II. 
end of the tail, and the third the number of annual rings which the scale exhibited. The figures in brackets are the number of sclerites produced towards the last and incomplete annual ring. In the fourth column is noted the number of sclerites formed during each year's growth.

The first point of interest arising from this table is the great variations in length that occur between fish of almost the same age; thus the length for second year fish varies from $7 \cdot 9$ to $9 \cdot 6 \mathrm{~cm}$., increasing as the fish enters on its third year of life, so that in one case a fish of $25.5 \mathrm{~cm}$. in length was found to be but $2 \frac{3}{4}$ years old. Again, I have enumerated fishes in their third year of life with lengths, $15 \cdot 5 \mathrm{~cm}$., $25 \mathrm{~cm} ., 27 \cdot 3 \mathrm{~cm}$., and $32 \cdot 1$ $\mathrm{cm}$. respectively.

It is true that in the normal conditions there would in all probability not be these enormous differences in the lengths of fish of the same age, because the external conditions would be more or less uniform for the fish of the same district. This condition has not been fulfilled, for a few of the animals in the Table, for experimental reasons, have been subjected to temperature variations and changes in the amount of food. In many cases, where the length is great in proportion to the age the animals have probably received more food than one would expect them to get from their normal habitat.

A further point to be observed is that the number of sclerites formed in the scale seems to be correlated with the condition and length of the fish ; thus of the third year fish, marked $\dagger$, the one $15.5 \mathrm{~cm}$. long had but 28 sclerites, while of the others those with lengths $32 \mathrm{~cm}$. and $32 \cdot 1 \mathrm{~cm}$. had 62 , and 75 sclerites respectively. The three fish selected exhibit this phenomenon very clearly, but in practically all cases the same condition obtains. Thus I feel that I am right in stating that on the whole the sclerite formation and the growth in length are correlated.

J. Stuart Thomson, in his paper on the scales of the Gadidæ (p. 74), comes to the conclusion that intensive growth favours the production of a small number of sclerites.

To illustrate this he takes the case of a pollack three years of age and $27.62 \mathrm{~cm}$. in length. Examination of the scales showed the following number of sclerites for each year: year I, 13 ; year II, 13 ; year III, 18 . From this he goes on to say: "We have evidently here to deal with a rapidly grown fish, and this fact has expressed itself in the formation of the scale, in the small number of lines of growth for the first and second year. The more intensive the growth the smaller the number of the lines of growth. To compare with this we might take the case of a slower growing pollack, $44 \cdot 40 \mathrm{~cm}$. The scale of such a pollack shows the following lines : year I, 21 ; year II, 29 ; year III, 18 ; year IV, $2 . "$

I do not quite understand this statement because, according to Thomson's Table, the first fish mentioned, of length $27 \cdot 62$, was small 


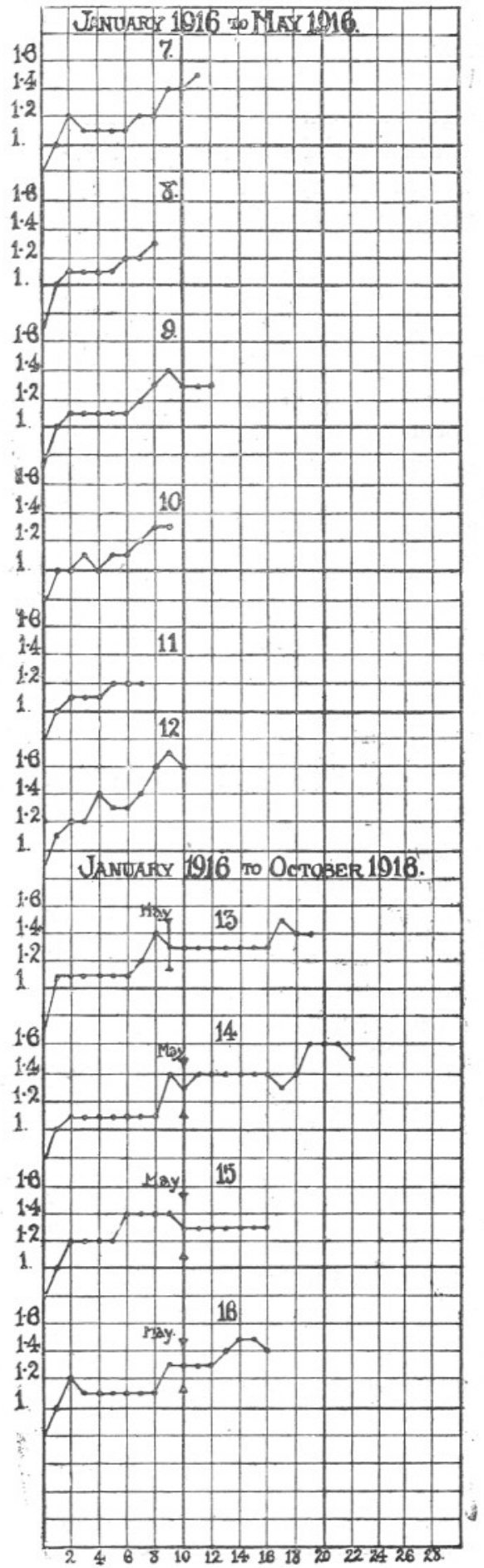

FIg. 6.-Partial curves of scales from fish living in hot water tank. In this and the following figure the vertical lines passing through some of the scales are the lines of demarcation between two periods of the experiment. The figure over each curve indicates the corresponding scale in Tables III. and IV.

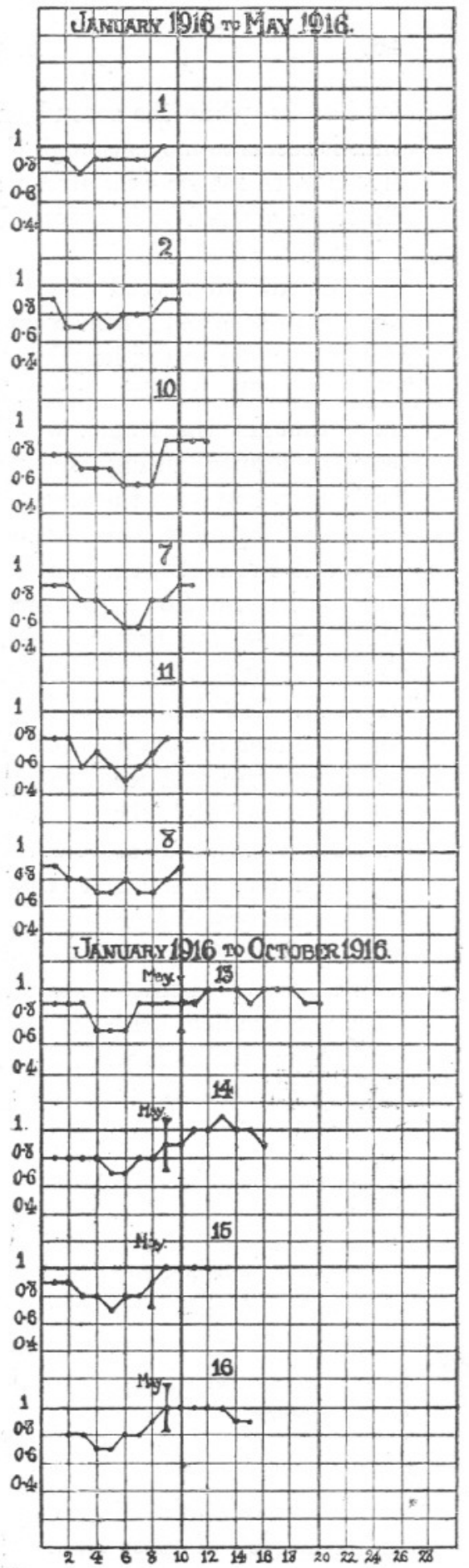

FIg. 7.-Partial curves of scales from fish living in cold water tank. 
for its age, while the second one, of length $44.4 \mathrm{~cm}$. was about normal, thus it seems to me as though the first fish instead of showing an intensive growth rather exhibited a slow one. If this is so the conclusion Thomson arrived at is practically reversed, and rather is in accordance with my results.

Cases are often seen where a fish is in good condition, but the total number of sclerites is somewhat small as is also the length; such a one is the $4 \frac{1}{2}$ year old fish of length $27 \cdot 8 \mathrm{~cm}$., the scale curve of which is seen in Fig. $4 \mathrm{~A}$. The condition when examined was excellent, and one would have thought the length would have been greater. The number of sclerites formed during each year of growth is, however, instructive; during the first year there were nine, the second eleven, but during the two following years this number was increased to twenty-four for the third and twenty for the fourth year. I should interpret this as meaning that during the first two years of life the conditions for growth were unfavourable, but that they improved later on. This is borne out by the four-year-old fish, of length $26.8 \mathrm{~cm}$., whose scale curve is seen in Fig. $4 \mathrm{X}$. The condition of the animal was poor when examined and the total number of sclerites very few, thirty-four. During the first year only four were produced, and but six and five for the third and fourth years respectively. The number sixteen for the second year seems to indicate a period of more favourable conditions.

A summary of the first part of my investigations is that the age of Plaice and probably Flounders can be accurately ascertained by the examination of the scales without reference to the otoliths. Having seen that two distinct breadths of sclerites are produced during each year, the problem arises as to what are the factors concerned in their production, and it is with the experiments which I performed in order to ascertain this, that the next part of the paper deals.

\section{PART II.}

Previous workers on fish scales have assumed that the annual rings are produced either by seasonal variations in the temperature of the water, or by fluctuations in the food supply. I therefore resolved to ascertain by experiment what part these two factors actually played in scale growth.

\section{METHODS.}

Four tanks at the Plymouth Laboratory were placed at my disposal and into each of these from 12-16 fish were placed; both Plaice and Flounders being used. 


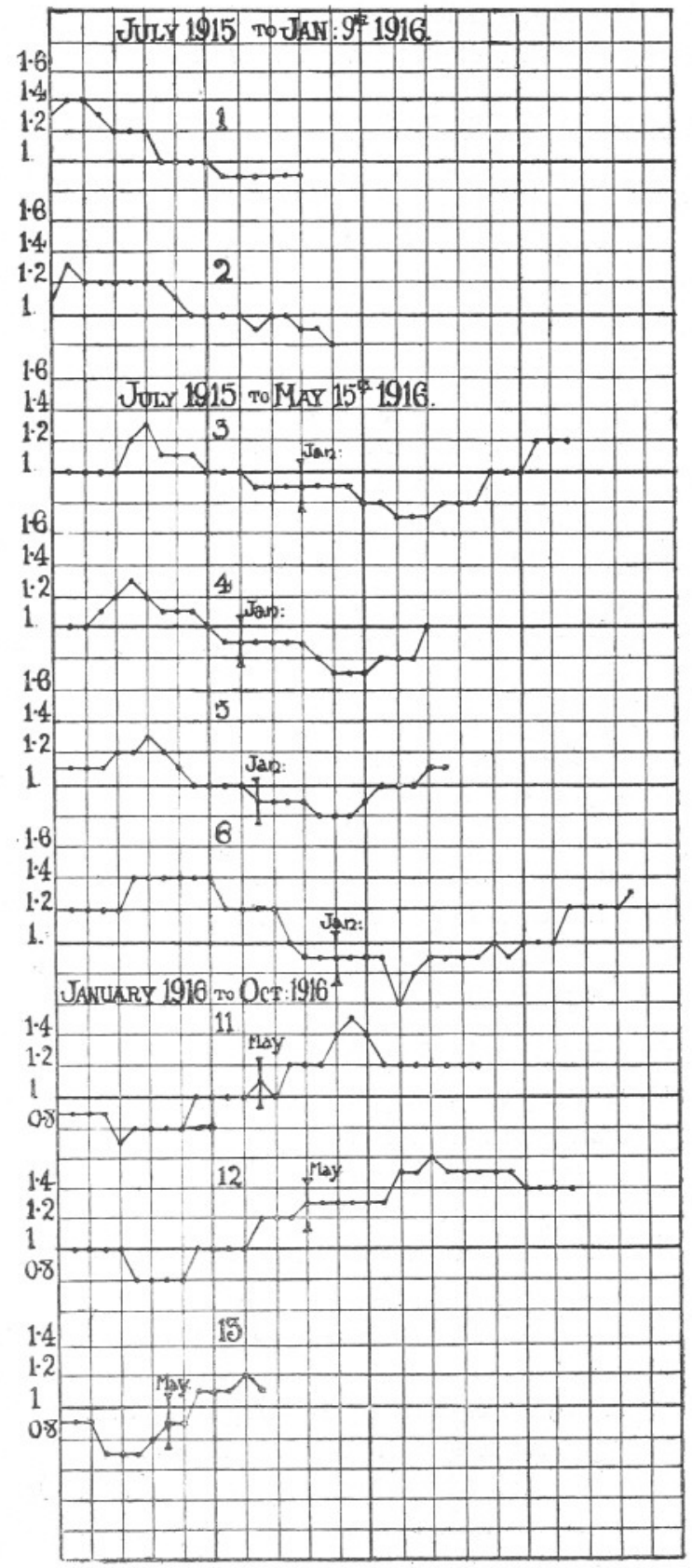

FIG. 8.-Partial curves of scales taken from fish which had been fed abundantly. The number over each curve indicates the corresponding scale in Table V.

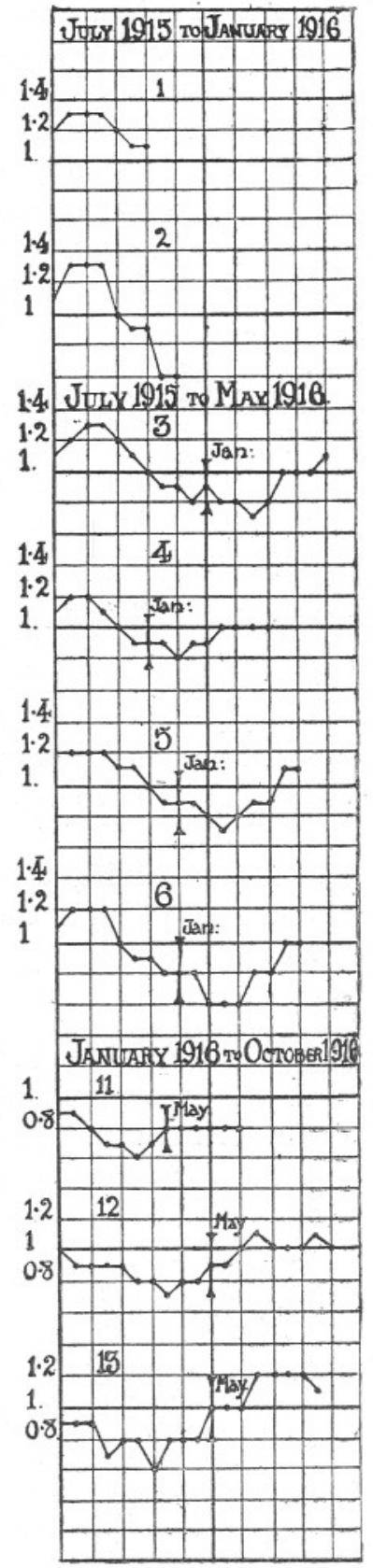

Fig. 9.-Partial curves of scales taken from fish which had been scantily fed. The number over each curve indicates the corresponding scale in Table VI. 
Before putting the fish into the tanks scales were taken from the regions just above the pectoral fin and examined and scale curves made from each specimen.

The length of each fish was recorded and the animal marked. This was done by tying pieces of various coloured silks round the tail.

The experiments started about the middle of July, 1915. On January 9th, 1916, each fish was re-examined and scales taken from the same region as before, the length also being recorded.

The fish were then allowed to remain undisturbed until the following May, when about half a dozen from each tank were killed by chloroform, and scales again taken. This method of procedure was necessary because of my having, during the course of the experiments, removed from Plymouth to Manchester and I was unable to go to Plymouth in order to remove the scales from the living animals. The remaining fish were kept under experimental condition until the beginning of October, 1916, when they were killed, measured, and scale samples sent to me.

The experimental conditions under which the animals lived were as follows: the temperature of the water in two of the four tanks was varied, one being kept at a temperature as high or higher than the normal summer temperature of the sea water in the tanks at Plymouth, while the temperature of the other was kept as low as possible.

The remaining two tanks were used for feeding experiments, the temperature being that of the sea water in circulation in the tanks at Plymouth.

\section{HOT AND COLD TANKS.}

The temperature in the hot tank was obtained by running in sea water that had previously been heated. During the first part of the experiment, that is from July to January, the results were not very satisfactory, because the heating apparatus was turned off during the night and the tank water allowed to cool. Although it never reached the normal temperature yet there was a difference of $3-4^{\circ} \mathrm{C}$. between the night and day temperatures. After January, however, a new apparatus was kindly devised by Mr. Matthews which maintained the water at a constant temperature day and night.

The artificial cooling of the cold tank was done by running sea water through glass tubes, which were surrounded by ice. This apparatus was quite successful in cooling the water, but as the ice was not renewed during the night the temperature of the tank rose a little. The result of this was a slightly fluctuating temperature, which was, however, not sufficient to nullify the experiments, the fluctuations not being more than $3^{\circ} \mathrm{C}$. in the summer, and between $1^{\circ}$ and $2^{\circ}$ for the winter and autumn. 
I give below the average temperature for each month of the hot and cold tanks, together with that of the sea water in the tanks at Plymouth.

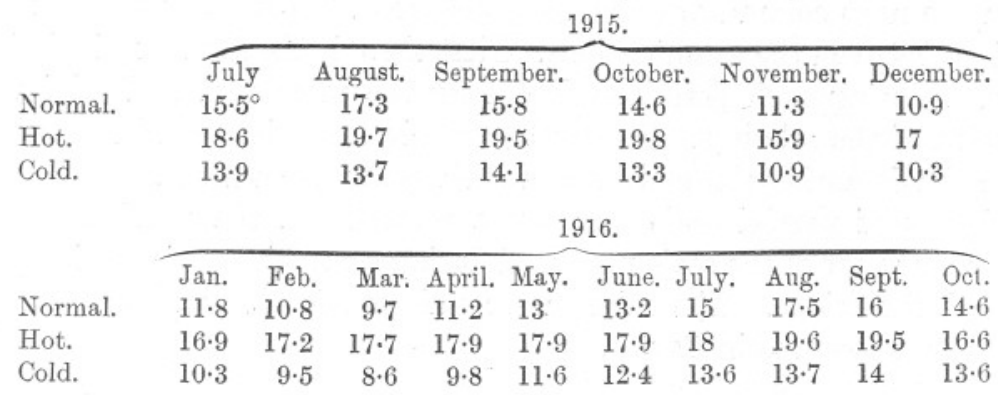

It will be seen that as regards the hot tank the temperature throughout was practically as high or higher than the highest temperature recorded for the normal sea water. Also the temperature was fairly constant from month to month.

As I have already indicated the cold tank records are not as satisfactory : in every month the temperature was below that of the normal, but in some cases it was above the winter temperature of the normal sea water. It was, however, in all cases far below the corresponding one for the hot tank.

\section{"ABUNDANT" AND "SCANTY" TANKS.}

These two tanks were the ones in which feeding experiments were conducted and the temperature was undisturbed. In the abundant tank the fish were fed excessively, that is to say, twice a day they were given as much food as they would take. The food was varied, sometimes squid, at other times worms, etc.

The fish in the scanty tanks were by no means so well treated : they were given very little at a time and never more than once a day : it was common to feed every other day.

In January control fish were started whose scale growth was investigated in exactly the same way as the others.

These fish were kept in an aquarium tank together with other species and were treated in exactly the same way, being fed once a day neither abundantly nor scantily.

RESULTS OF THE EXPERIMENTS.

In Tables II, III, IV, V, VI (p. 494), I have given the details of the fish experimented upon: the ages as computed from both otolith and scale are found in column two; and it is worth noting here, that the age was first determined from the scales and then confirmed by the otolith at 
the end of the experiments. In no case was there any discrepancy between the two results.

In the next column are given the details of the scale growth for the periods between the examinations. First there is the number of sclerites formed during each period, followed by the maximum and minimum breadth of the sclerites. Finally I have given the increase in length of the animals during the periods and their general condition.

Figures of partial scale curves are reproduced, the portion figured being that part of the scale produced during successive periods of experimental conditions. The micrometer unit employed was the same as that for the curves in Part I.

\section{CONTROL FISH.}

The control tank, Table II, shows how uniform was the growth of both scale and fish during the two periods of the experiment. With the exception of those fish whose condition was not very good the increase in length from January to May is remarkably constant, as is also the number of sclerites formed. Also the maximum breadth is between 0.9 and 1.1 and the minimum between 0.8 and 0.6 . Fig. 5 , which represents the scale curves of some of these fish, is interesting in showing how closely the curve follows the temperature changes. They all start with a relative breadth for the sclerites of 0.9 or 0.8 , which falls to a minimum in about the middle of the curve, then gradually rises to either 0.9 or 1.1 When we remember that the temperature in January was $11 \cdot 8^{\circ} \mathrm{C}$. falling to $9 \cdot 7^{\circ} \mathrm{C}$, in March and gradually rising to $13^{\circ} \mathrm{C}$, by Nay, these curves seem very significant.

The growth during the period from May,-1916, to October, 1916, is equally interesting. The increase in length is a little greater than during the previous portion of the experiment, as would be expected. As regards the sclerites we note that the maxima and minima are greater in accordance with the higher temperature during these months. The scale curves also follow very closely expectation, if we assume that temperature is the directive agent in the production of wide or narrow sclerites.

In the curves of scales figured for the period, January to October, I have drawn a line through the portion where the growth up to May ended. This procedure I have followed in all the scale curves reproduced in the figures.

\section{HOT AND COLD TANKS.}

At the commencement of the experiment great trouble was encountered in keeping the animals in the hot tank in good condition, and several times the experiment had to be restarted owing to the fish either dying or getting into extremely poor condition. This was possibly due to the daily rise and fall of the temperature caused by the imperfect apparatus 
employed, because, after January, when the new apparatus had been installed this difficulty was not encountered, the fish in most cases appearing in quite normal condition. On account of this the results of the experiments between July, 1915, and January, 1916, have not received much attention, and although scale curves were made from each fish they have not been reproduced. This is not because they at all contradict the results of subsequent experiment, but because in most cases the fish had not lived long enough to exhibit much scale growth.

Of the six fish which did survive through the whole period, only three were at all in good condition, the others being much emaciated (see Table III).

From January to May the increase in length was in most cases a little greater than in the control tank, though the number of sclerites produced was practically the same. What is of great interest and importance, however, is the difference in the maximum and minimum breadths as compared with the controls. In no case was the maximum below 1.2 and the smallest minimum was 1 . Further, the difference in breadth between the maxima and minima is small, in only two cases exceeding $0 \cdot 4$. This is of course as it should be, as the difference in temperature during the period was never greater than $1^{\circ} \mathrm{C}$.

The scale curves, Fig. 6 (p. 479), are interesting in showing great similarity; there is for all a sudden rise from below the 1 unit standard to a breadth of from 1 to $1 \cdot 2$. This width is maintained for a number of sclerites until a second rise is observed near the end of the period. These two rises, I think, synchronise with the increased temperature: first from $11.8^{\circ} \mathrm{C}$., the normal for January, to $16.9^{\circ} \mathrm{C}$.; and secondly, between the end of March and beginning of April when the temperature was raised $1^{\circ} \mathrm{C}$.

A further point which must not be overlooked is that at this period of the year, fish living in untreated water would be forming narrow sclerites, and their scale curve would be one showing a minimum, not a maximum. This I have shown to be the case with the control fish; a comparison of their scale curves with those of Fig. 6, exhibits this in a striking way.

Of those fish that remained alive until October, the width of the sclerite formed at the end of the May period is maintained constant until a still greater width is attained at the margin of the scale. This, I believe, was due to the water in the tank rising from $17.9^{\circ}$ to $19.7^{\circ}$ between July and August.

The part of the table dealing with this period of experiment for the hot tank is almost a repetition of that for January to May.

I should like to call attention at this point to the two scales No. 12 and No. 15. The first of these shows an abnormally high width, while 
the second, though normal as regards the width of its sclerites, is remarkably deficient in them.

The fish to which scale No. 12 belonged was in very good condition and young: this was not the case with the fish from which No. 15 was taken. I attribute these peculiarities to nutriment, but will deal especially with this aspect of the problem in a later part of the paper.

The growth of the fish in the cold tank was, on the whole, very good. Table IV, which deals with the details of the fishes experimented upon, seems to show that the increase in length was slightly greater than that of the animals in the hot tank. There are, however, possibilities of error, such as faulty measurements and the small number of fish experimented upon, which make it impossible to draw any definite conclusions.

The figures of the maxima and minima for the sclerites for each period are, however, striking when compared with those of the corresponding periods for the hot tank animals. The figures are also lower than those for the control tank, though the difference is not very marked. This is, however, to be expected when it is remembered that it was only possible to keep the temperature of the cold tank a few degrees below the normal.

The scale curves, Fig. 7 (p. 479), are very interesting in showing the marked difference between them and those of the hot tank for the period of January to May. In all cases, and this was found in scales not figured, the curve never rises above unity, while in the hot tank it never falls below that width.

For the period January to October, the curves have a tendency to rise; there is an increased width of sclerites for the months July to September, but the greatest width does not approach that of the hot tank fish for the same months.

Compared with the control scale curves, there is similarity, but we find that the widths are more uniformly low.

When considered in relation to the temperature for each month the curves follow very closely the varying changes in the degree of heat, which the water possessed in which the animals lived.

As in the case of the hot tank scale curves we note that these curves also follow one another very closely, only differing in minor degrees.

The results of the experiments on the scales of fishes living in artificially heated and cooled water seems to indicate clearly that the temperature of the water has a very marked effect on the width of the sclerites produced. It is well to remember in connexion with this that the feeding of the fish in the two tanks was exactly the same.

\section{ABUNDANT AND SCANTY TANKS.}

As I have already said in these two tanks the temperature of the water was not altered. The only difference in the way the fish were treated 
was as regards the amount of food given to them. As the experiment in the case of these two classes of animals progressed satisfactorily from the very beginning, that is from July, 1915, until October, 1916, I have included scale curves in the figures for the period, July, 1915, to January, 1916.

As regards the sclerites the Tables V and VI shows a uniformity among the fishes of the abundant tank which were in good condition; of those in a bad condition at the end of the experiment I shall treat later.

Figs. 8 and 9 (p. 481) are scale curves of abundant and scanty fed fish respectively. They are very alike in their general aspect as regards the type of curve, and in each set the maxima and minima are produced at approximately the same time and in accordance with the rise or fall of temperature at that time. Further it will be noted that there is correspondence between the course of these curves and those of the control fish scales of the same period.

If food were the predominating cause of the winter and summer rings of the scales, the expectation would be that the scales from the two sets of fish would have been remarkably different: this, however, we see is not the case.

The increase in length of the fish, as shown in the table, is very different, the scantily fed animals not increasing to any great extent. Also the number of sclerites produced by the abundantly fed fish is in excess of those produced by the animals in any of the other tanks.

Figs. 8 and 9 show very clearly the great difference between the number of sclerites produced for a given period by fish in the two tanks.

The last scale figured, No. 13 of Fig. 8, is interesting in this connexion : the condition of the animal was never very good, and at the end of the experiment the increase in length was only $1 \mathrm{~cm}$. ; that is, for a period of nine months this animal had only added $1 \mathrm{~cm}$. to its length. In accordance with this we note that but 13 new sclerites had been added to the scale; thus though the animal had been given the opportunity for feeding well it had for some reason not availed itself of it, and had thus become comparable with the fish of the scanty tank.

The converse of this occurred once or twice with the scantily fed fish, in that some of the more vigorous animals managed to obtain more than their share of the food given to them; with the result that they increased in length much more than did their fellows and developed many more sclerites. Most examples of this have been omitted from the table, but scale No. 14 for the period of May to October exhibits the condition to a small extent.

In Fig. 10 (p. 473) are seen a few curves of the scales of fish from various tanks which were in bad condition. The first two curves are from two fish from the abundant tank, No. 8 and 9 in the table. In February, 
1916, they both died in an apparently exhausted condition. 'The same applies to the scales S. 8 , S. 10, being from fishes 8 and 10 of the scanty tank. It will be seen that the curves show the salient features of all those for that period taken from fish living in unheated water. They are characteristic, however, in showing the possession of very few sclerites, and in having the width of the sclerites slightly less than is usual.

Scale curve H. 15 is the most interesting in showing the predominance of temperature over nutrition in regard to sclerite form. It is a curve of a scale from a fish living in the hot tank, No. 15. From January to May the animal was in fairly good condition and produced 10 broad sclerites: from May to October, however, its condition was bad, but in spite of this six sclerites were produced and instead of being narrow, as might have been expected if food were the cause of width variation, they retained the broad width of $1 \cdot 3$.

In all cases the same effect is seen, that the lower nutrition, leading to a poor condition, results in the lessening of the number of sclerites produced; but does not affect the breadth.

Reference to the tables will show that where the condition of a fish is reported as poor, very thin, etc., the number of sclerites produced is small, but the maximum and minimum widths remain similar to those for fish in good condition.

\section{CONCLUSIONS.}

The conclusions which I draw from the result of these experiments on the scale growth of fish is, that the broad summer bands, which are caused by the sclerites formed during that period being wide, and the narrow winter bands, produced by narrow sclerites, are due to changes in the temperature of the water in which the animals are living. High temperatures, such as are found in the summer months, lead to the formation of broad sclerites, while the narrow ones are called forth by low winter temperatures.

Owing to the temperature of the water varying from month to month, or even from week to week, the scale curves do not show a continuous rise and fall, but exhibit at certain places secondary elevations or depressions, which I have termed secondary maxima and minima. These, I believe, to be due entirely to the above-mentioned variations in the monthly temperatures.

The amount of food which the fish consumes and its general condition does not affect the production of summer and winter bands: the only effect which poor nutrition seems to have on the scales is a tendency for the production of few sclerites. High food consumption leads to a high sclerite formation. 
Thus the number of sclerites formed seems to follow hand in hand with the general metabolism of the animal.

Little experimental work on the cause of the appearance of winter and summer rings has been done. Winge came to the conclusion that external conditions were the causative agents, because of the identical appearance of the scales of cod captured off the Faroes.

On August 11th, 1911, six cod were captured and samples of scales taken. They were then liberated and were recaptured simultaneously nine months later. Of these, three fish of approximately the same size were selected, and from each fish five scales were taken, measured and a curve made. It was found that all the scale curves thus drawn were exceedingly alike, so much so as to include peculiar deviations in the course of the curves. Winge argues from this that external conditions were responsible for the form of the curves, because the fish must have lived together for the nine months before recapture, and must therefore have been subjected to similar external conditions, such as temperature and salinity. The supply of nourishment in the water must also have been the same for the three animals.

This experiment certainly indicates that it is the environment which controls the course of scale growth, but it does not show what particular factor is the principal agent.

J. Stuart Thomson in his paper on the scales of Gadidæ (p. 100) states that in his opinion it is the amount of food supply, rather than variation in temperature, which brings about the formation of annual rings in scales. His reasons for coming to this conclusion are two: The first rests upon the evidence afforded by a whiting which was kept in captivity in a tank at Plymouth from May, 1902, until July, 1903. The water in the tank was not treated in any way, and the animal was fed daily. When in July, 1903, the scales were examined the sclerites appeared of the same width, and no winter or summer rings were detected. The sclerites also seemed to be narrower than is the case with fish captured from the sea.

This result is in direct opposition to that which I have obtained, for my fish in the two tanks when the water was not artificially cooled or heated all showed distinct rings.

Also if food were the determining factor one would have expected that a fish fed daily, and which increased in length from 10-20 mm. to $21.5 \mathrm{~cm}$. in fourteen months as Thomson records, would have exhibited broader, or at any rate as broad, sclerites as fish of the same age captured from the sea. Yet this is not so, the sclerites were narrower.

Again the total number of sclerites produced was about 50, but whiting from the sea of the same age showed about 43 . This indicates that the animal experimented upon was in good condition and corresponded to my fish which were abundantly fed. 
The second piece of evidence (p. 57) that Thomson adduces for his opinion is that deep-sea fishes are not exposed to seasonal variations of temperature and should not, therefore, show annual rings on their scales. In order to determine if this were so he examined scales from a haddock captured from 8-14 fathoms depth of water, and compared them with others taken from a haddock from $60-80$ fathoms. The annual rings were as clearly marked in the latter as in the former.

It should be pointed out that $60-80$ fathoms is not really deep water, and that seasonal variation does not disappear until a depth of 100 fathoms is reached. Indeed according to some oceanographers the variation would seem to extend to a slight extent to much greater depths.

In conclusion I wish to express a great gratitude to Dr. Allen for the interest he has taken in my work and for the many suggestions he has made to me : also for the facilities he has given me to enable the experimental part of the work to be carried out. I must also express my thanks to Mr. D. J. Matthews for suggestions regarding the apparatus used for the heating and cooling of the water in the tanks. My thanks are also due to Mr. A. J. Smith for the feeding and care of the fish during the period when I was away from Plymouth.

\section{REFERENCES.}

Cunningham, J. T. Zones of Growth in the Skeletal Structures of Gadidæ, and Pleuronectidæ. Annual Report of the Fishery Board of Scotland. 1905.

Esdafle, P. C. Intensive Study of the Scales of Three Specimens of Salmo salar. Memoirs and Proceedings of the Manchester Lit. and Phil. Soc. 1911-12.

Esdaile, P. C. The Scientific Results of the Salmon Scale Research at Manchester University. Memoirs and Proceedings of the Manchester Lit. and Phil. Soc. 1912-13.

Thomson, J. Stuart. Periodic Growth of Scales in Gadidæ as an Index of Age. Journ. Marine Biol. Assoc. 1904.

WINGE, 0. On the Value of the Rings in the Scales of the Cod as a Means of Age determination. Meddelelser fra Kommissionen for Havundersogelser. 1915 . 
TABLE I

\begin{tabular}{|c|c|c|c|c|c|c|c|c|c|}
\hline $\begin{array}{l}\text { Age } \\
\text { by } \\
\text { otolith. }\end{array}$ & $\begin{array}{l}\text { Length } \\
\text { in } \mathrm{cm} .\end{array}$ & $\begin{array}{l}\text { No. of } \\
\text { annular } \\
\text { rings. }\end{array}$ & I. & $\begin{array}{l}\text { II } 8 \\
\text { II. }\end{array}$ & $\begin{array}{l}\text { numb } \\
\text { iccess } \\
\text { III. }\end{array}$ & IV. & $\begin{array}{l}\text { scleri } \\
\text { ars. } \\
\text { V. }\end{array}$ & VI. & Species \\
\hline fl & $2 \cdot 6$ & $1(+6)$ & 19 & - & - & - & - & - & not determ \\
\hline el & $2 \cdot 7$ & $1(+8)$ & 10 & - & - & - & - & - & , \\
\hline bl & 3 & $1(+8)$ & 13 & - & - & 一 & 一 & - & , \\
\hline$y 1 \frac{1}{2}$ & $3 \cdot 9$ & $1(+11)$ & 12 & - & - & - & - & - & " \\
\hline$x 1 \frac{3}{4}$ & $7 \cdot 1$ & $1(+15)$ & 12 & - & - & - & - & - & Plaice \\
\hline 2 & $7 \cdot 9$ & 2 & 12 & 20 & - & - & - & - & Flounder \\
\hline 2 & $7 \cdot 9$ & 2 & 10 & 26 & - & - & - & - & , \\
\hline $\mathrm{K} 2$ & $8 \cdot 2$ & $2(+6)$ & 16 & 32 & - & - & - & - & , \\
\hline J2 & $8 \cdot 9$ & $2(+4)$ & 13 & 39 & - & - & - & 一 & Plaice \\
\hline L2 & $9 \cdot 1$ & $2(+5)$ & 14 & 22 & - & - & - & - & , \\
\hline 2 & $9 \cdot 1$ & $2(+3)$ & 12 & 30 & - & & - & - & Flounder \\
\hline 2 & $9 \cdot 6$ & $2(+7)$ & 11 & 36 & - & - & - & - & " \\
\hline $2 \frac{3}{4}$ & $14 \cdot 9$ & $2(+16)$ & 11 & 14 & - & - & - & - & , \\
\hline $2 \frac{3}{4}$ & $17 \cdot 5$ & $2(+18)$ & 14 & 19 & - & - & - & - & Plaice \\
\hline $2 \frac{3}{4}$ & $17 \cdot 6$ & $2(+11)$ & 8 & 18 & - & - & - & - & , \\
\hline $2 \frac{1}{2}$ & 19 & $2(+2)$ & 15 & 17 & - & - & - & - & Flounder \\
\hline $2 \frac{1}{2}$ & $20 \cdot 2$ & $2(+21)$ & 14 & 32 & - & - & - & - & Plaice \\
\hline $2 \frac{3}{4}$ & $25 \cdot 5$ & $2(+26)$ & 16 & 16 & - & - & - & - & Flounder \\
\hline$\dagger 3$ & $15 \cdot 5$ & 3 & 6 & 10 & 12 & - & - & - & Plaice \\
\hline 3 & 20 & $3(+2)$ & 10 & 12 & 6 & - & - & - & Flounder \\
\hline $3 \frac{3}{6}$ & $21 \cdot 3$ & $3(+12)$ & 8 & 10 & 18 & - & - & - & Plaice \\
\hline
\end{tabular}

$$
\begin{array}{cc}
\begin{array}{c}
\text { Condition } \\
\text { of }
\end{array} & \begin{array}{c}
\text { Date scale } \\
\text { was taken }
\end{array} \\
\text { fish. } & \text { from fish. }
\end{array}
$$

\begin{tabular}{|c|c|}
\hline ", & , \\
\hline " & $"$ \\
\hline ", & ” \\
\hline good & July 28,1915 \\
\hline very good & , \\
\hline , & " \\
\hline , & May 28,1915 \\
\hline , & " \\
\hline good & , \\
\hline very good & ", \\
\hline , & , \\
\hline good & $"$ \\
\hline
\end{tabular}

$$
\text { termined very good June 12, 1915* *aptured }
$$

very good June 12, 1915

, May, $1916 \quad *$ H. Jan.-May, 1916

, Sept., 1915 captured

excellent May 28, 1915

," May 12, 1916 A. July, 1915-May, 1916

fair Aug., 1915 captured

, May 28, 1915 ,

good Jan. 9, 1916 C. July, 1915-Jan., 1916 
TABLE I-continued.

\begin{tabular}{|c|c|c|c|c|c|c|c|c|c|}
\hline $\begin{array}{l}\text { Age } \\
\text { by }\end{array}$ & Length & $\begin{array}{l}\text { No. of } \\
\text { annular }\end{array}$ & & $\begin{array}{l}\text { rage } \\
\text { in st }\end{array}$ & $\begin{array}{l}\text { numl } \\
\text { tecess }\end{array}$ & $\begin{array}{l}\text { er of } \\
\text { ive ye }\end{array}$ & $\begin{array}{l}\text { scleri } \\
\text { ars. }\end{array}$ & & \\
\hline otolith. & in $\mathrm{cm}$. & rings. & I. & II. & III. & IV. & V. & VI. & Species. \\
\hline 3 & $21 \cdot 5$ & 3 & 8 & 20 & 19 & - & 一 & - & Flounder \\
\hline H $3 \frac{1}{4}$ & $22 \cdot 6$ & $3(+12)$ & 10 & 27 & 23 & - & 一 & 一 & Plaice \\
\hline 3 & 25 & $3(+12)$ & 11 & 24 & 19 & - & - & - & , \\
\hline $3 \frac{1}{2}$ & $25 \cdot 2$ & $3(+6)$ & 14 & 24 & 20 & - & 一 & - & " \\
\hline 3 & $27 \cdot 3$ & 3 & 16 & 22 & 25 & - & - & 一 & Flounder \\
\hline $3 \frac{1}{2}$ & $27 \cdot 6$ & $3(+6)$ & 11 & 16 & 22 & - & - & - & Plaice \\
\hline 3 & $28 \cdot 3$ & $3(+15)$ & 6 & 32 & 26 & - & - & 一 & Flounder \\
\hline $3 \frac{1}{4}$ & $28 \cdot 4$ & $3(+18)$ & 9 & 24 & 31 & - & - & - & , \\
\hline $3 \frac{3}{4}$ & $28 \cdot 6$ & $3(+20)$ & 7 & 17 & 12 & - & 一 & - & Plaice \\
\hline 3 & $29 \cdot 6$ & 3 & 9 & 21 & 28 & - & 一 & - & Flounder \\
\hline 3 & $29 \cdot 6$ & $3(+1)$ & 7 & 28 & 25 & - & - & - & ", \\
\hline $3 \frac{3}{4}$ & $30 \cdot 6$ & $3(+10)$ & 15 & 24 & 32 & - & - & - & Pläice \\
\hline$W 3_{4}^{3}$ & $30 \cdot 5$ & $3(+8)$ & 11 & 23 & 17 & - & 一 & - & Flounder \\
\hline $3 \frac{1}{2}$ & $30 \cdot 2$ & $3(+6)$ & 11 & 22 & 16 & - & 一 & - & ", \\
\hline $3 \frac{1}{2}$ & 31 & $3(+8)$ & 14 & 14 & 20 & - & 一 & - & ", \\
\hline P3 & 32 & $3(+7)$ & 10 & 30 & 25 & - & - & - & Plaice \\
\hline$\dagger 3$ & $32 \cdot 1$ & 3 & 16 & 26 & 20 & - & 一 & - & , \\
\hline$\uparrow 3$ & $32 \cdot 1$ & 3 & 21 & 26 & 28 & - & - & - & $"$ \\
\hline $4 \frac{1}{2}$ & $24 \cdot 7$ & $4(+3)$ & 6 & 16 & 6 & 10 & - & - & ", \\
\hline $4 \frac{1}{4}$ & $25 \cdot 5$ & $4(+2)$ & 8 & 8 & 27 & 24 & - & 一 & Flounder \\
\hline 4 & $26 \cdot 7$ & $4(+2)$ & 8 & 22 & 14 & 14 & - & - & \\
\hline 4 & 27 & $4(+2)$ & 12 & 17 & 12 & 18 & - & - & Plaice \\
\hline
\end{tabular}

\begin{tabular}{|c|c|c|}
\hline $\begin{array}{l}\text { Condition } \\
\text { of } \\
\text { fish. }\end{array}$ & $\begin{array}{l}\text { Date scale } \\
\text { was taken } \\
\text { from fish. }\end{array}$ & \\
\hline good & Aug., 1915 & captured \\
\hline , & May 28,1915 & 1 \\
\hline " & Jan., 1916 & C. July, 1915-Jan., 1916 \\
\hline , & Aug., 1915 & ", \\
\hline , & Jan., 1916 & $"$ \\
\hline , & May, 1915 & ", \\
\hline , & ", & , \\
\hline excellent & Sept., 1915 & $"$ \\
\hline , & Jan. 9, 1916 & A. July, 1915-Jan., 1916 \\
\hline " & Aug., 1915 & ", \\
\hline ", & June, 1915 & , \\
\hline " & May, 1916 & A. July, 1915-May, 1916 \\
\hline good & June 12, 1915 & captured \\
\hline$"$ & July, 1915 & " \\
\hline fair & May, 1915 & ", \\
\hline excellent & June 12,1915 & $"$ \\
\hline " & May, 1915 & A. July, 1915-May, 1916 \\
\hline , & June, 1915 & captured \\
\hline poor & May, 1915 & ", \\
\hline fair & Aug., 1915 & $"$ \\
\hline , & Sept., 1915 & S. July, 1915-Sep \\
\hline
\end{tabular}




$\begin{array}{cllrrrrrcc}1 \frac{1}{2} & 27 \cdot 8 & 4(+6) & 9 & 11 & 24 & 20 & - & - & \text { Plaice } \\ 4 \frac{3}{4} & 28 & 4(+8) & 8 & 10 & 15 & 16 & - & - & \text { Flounder } \\ 4 \frac{1}{2} & 28 \cdot 5 & 4(+5) & 6 & 14 & 7 & 15 & - & - & , \\ 4 \frac{1}{2} & 29 \cdot 4 & 4(+15) & 8 & 20 & 20 & 19 & - & - & , \\ 4 \frac{1}{4} & 29 \cdot 5 & 4 & 12 & 30 & 16 & 24 & - & - & , \\ 4 \frac{1}{4} & 30 & 4(+5) & 10 & 12 & 16 & 18 & - & - & , \\ 4 & 30 & 4 & 13 & 10 & 13 & 31 & - & - & , \\ 4 \frac{1}{2} & 30 \cdot 5 & 4(+6) & 19 & 10 & 9 & 34 & - & - & \text { Plaice } \\ 4 & 30 \cdot 6 & 4(+4) & 18 & 12 & 12 & 17 & - & - & \text { Flounder } \\ 4 & 30 \cdot 6 & 4(+6) & 14 & 10 & 15 & 8 & - & - & \text { Plaice } \\ 4 & 30 \cdot 6 & 4(+5) & 18 & 18 & 22 & 22 & - & - & \\ 4 & 33 & 4(+7) & 4 & 23 & 18 & 14 & - & - & \text { Flounder } \\ 43 & 33 \cdot 5 & 4(+10) & 8 & 24 & 30 & 14 & - & - & \text { Plaice } \\ \text { F4 } & 35 \cdot 6 & 4(+10) & 12 & 17 & 18 & 25 & - & - & , \\ \text { X4 } & 26 \cdot 8 & 4(+3) & 4 & 16 & 6 & 5 & - & - & \text { ", } \\ 5 \frac{1}{4} & 30 \cdot 5 & 5(+3) & 10 & 8 & 10 & 12 & 15 & - & , \\ \text { E5 } & 31 \cdot 2 & 5(+3) & 8 & 15 & 24 & 18 & 16 & - & \text { Flounder } \\ \text { D5 } & 32 \cdot 5 & 5(+15) & 12 & 17 & 14 & 18 & 17 & - & \text { Plaice } \\ \text { B5 } & 35 & 5(+7) & 5 & 10 & 30 & 9 & 18 & - & , \\ 6 \frac{1}{2} & 34 \cdot 5 & 6 & 6 & 8 & 7 & 7 & 12 & 6 & \text { Flounder }\end{array}$

\begin{tabular}{llc} 
excellent & Jan., 1916 & captured \\
good & Sept., 1915 &, \\
", & May, 1915 &, \\
very good & Aug., 1915 &, \\
excellent & Sept., 1915 &, \\
good & June, 1915 &, \\
very good & Sept., 1915 & H. July-Sept., 1915 \\
\multicolumn{2}{c}{, June, 1915 } & captured
\end{tabular}

good May, 1915

, Jan., 1916

„ Aug., 1915

A. July, 1915-Jan., 1916 captured

very good Jan., $1916 \quad$ S. July, 1915-Jan., 1916

good Sept., 1915 C. July, 1915-Sept.,1915 excellent May 28, 1915 captured

poor Jan. 9, 1916

fair , ",

good

, May 28,1915

very good

fair

* In the last column the word captured means the animal was taken straight from the sea, and did not live under experimental conditions before the seales were examined. A denotes that the animal lived in abundant tank; $\mathrm{S}$ in the scanty; $\mathrm{H}$ in the hot, and $\mathrm{C}$ in the cold tank before the scales were examined. 
Control Tank

\begin{tabular}{|c|c|c|c|c|c|c|c|c|c|c|c|c|c|c|}
\hline \multirow{2}{*}{\multicolumn{2}{|c|}{$\begin{array}{l}\text { Age in } \\
\text { years. }\end{array}$}} & \multicolumn{7}{|c|}{ January, 1916-May, 1916.} & \multicolumn{6}{|c|}{ May, 1916-October, 1916.} \\
\hline & & Species. & $\begin{array}{c}\text { No. of } \\
\text { sclerites. }\end{array}$ & Max.* & Min. & $\begin{array}{l}\text { Length I } \\
\text { in } \mathrm{cm} .\end{array}$ & $\begin{array}{c}\text { Increase in } \\
\text { length. }\end{array}$ & Condition. & $\begin{array}{l}\text { No. of } \\
\text { sclerites. }\end{array}$ & Max. & Min. & Length. & $\begin{array}{l}\text { nerease in } \\
\text { length. }\end{array}$ & Conditio \\
\hline 1 & 3 & Flounder & 10 & 1 & $\cdot 6$ & $25 \cdot 4-25 \cdot 6$ & $0 \cdot 2$ & very good & - & - & - & - & - & 一 \\
\hline 2 & 3 & , & 8 & 1 & $\cdot 7$ & $25-25 \cdot 1$ & $0 \cdot 1$ & good & - & - & - & - & - & - \\
\hline 3 & $3 \frac{3}{4}$ & , & 9 & .9 & $\cdot 7$ & $28 \cdot 9-29$ & $0 \cdot 1$ & ", & - & - & - & - & - & - \\
\hline 4 & $3 \frac{1}{2}$ & , & 10 & 1 & $\cdot 6$ & $29 \cdot 6-29 \cdot 7$ & $0 \cdot 1$ & , & - & - & - & - & - & - \\
\hline 5 & $4 \frac{1}{2}$ & Plaice & 11 & $1 \cdot 1$ & $\cdot 7$ & $30 \cdot 6-30 \cdot 7$ & $0 \cdot 1$ & $"$ & - & - & - & - & - & - \\
\hline 6 & $3 \frac{3}{4}$ & , & 4 & 1 & .5 & $28 \cdot 9-28 \cdot 9$ & 0 & fair & - & - & - & - & 一 & - \\
\hline 7 & 4 & $"$ & 7 & $\cdot 9$ & .8 & $28 \cdot 9-29$ & $0 \cdot 1$ & good & - & - & - & - & - & - \\
\hline 8 & 4 & , & 5 & 1 & $\cdot 7$ & $30 \cdot 5-30 \cdot 6$ & $0 \cdot 1$ & fair & - & - & - & - & - & - \\
\hline 9 & 3 & , & 7 & $1 \cdot 1$ & $\cdot 7$ & $25 \cdot 2-25 \cdot 3$ & $0 \cdot 1$ & good & - & - & - & - & - & - \\
\hline 10 & $2 \frac{3}{4}$ & Flounder & 9 & 1 & $\cdot 8$ & $23 \cdot 9-24$ & $0 \cdot 1$ & , & - & - & - & 一 & - & - \\
\hline 11 & 4 & , & 12 & $1 \cdot 1$ & $\cdot 8$ & $30 \cdot 0-30 \cdot 1$ & $0 \cdot 1$ & , & 13 & $1 \cdot 4$ & $1 \cdot 1$ & $30 \cdot 1-31 \cdot 1$ & 1 & excellen \\
\hline 12 & 4 & , & 12 & $1 \cdot 1$ & $\cdot 6$ & $29 \cdot 8-30$ & $0 \cdot 2$ & , & 12 & $1 \cdot 3$ & 1 & $30-31$ & 1 & , \\
\hline 13 & 3 & , & 13 & 1 & $\cdot 6$ & $26-26 \cdot 1$ & $0 \cdot 1$ & , & 10 & $1 \cdot 4$ & 1 & $26 \cdot 1-27$ & $0 \cdot 9$ & ", \\
\hline 14 & $3 \frac{1}{2}$ & Plaice & 12 & 1 & $\cdot 7$ & $28-28 \cdot 2$ & $0 \cdot 2$ & , & 14 & $1 \cdot 5$ & $1 \cdot 1$ & $28 \cdot 2-29$ & $0 \cdot 8$ & , \\
\hline 15 & 3 & , & 10 & $1 \cdot 1$ & $\cdot 8$ & $27 \cdot 5-27 \cdot 6$ & $0 \cdot 1$ & , & 9 & $1 \cdot 5$ & $1 \cdot 1$ & $27 \cdot 6-27 \cdot 8$ & $0 \cdot 2$ & fair \\
\hline 16 & 3 & , & 11 & 1 & $\cdot 6$ & $27 \cdot 1-27 \cdot 2$ & $0 \cdot 1$ & ", & 12 & $1 \cdot 4$ & 1 & $27 \cdot 2-28$ & $0 \cdot 8$ & good \\
\hline
\end{tabular}

* In the columns labelled Max. and Min. are given the maximum and minimum widths of the sclerites for the period. 
TABLE III

\section{Hot TANK}

January, 1916-May, 1916

\begin{tabular}{|c|c|c|c|c|c|c|c|}
\hline \multirow{3}{*}{$\begin{array}{c}\text { Age } \\
\text { in } \\
\text { years. }\end{array}$} & \multicolumn{7}{|c|}{ July, 1915-January, 19} \\
\hline & & NO. 0 & & & 1 & $\begin{array}{c}\text { Increase } \\
\text { in }\end{array}$ & \\
\hline & $\mathrm{sp}$ & iclerite: & . & n. & & length. & ond \\
\hline 13 & Flounder & 11 & $1 \cdot 8$ & $1 \cdot 3$ & $-25 \cdot 5$ & $0 \cdot 9$ & d \\
\hline 24 & & 18 & $1 \cdot 6$ & $1 \cdot 1$ & 1 & 1.6 & 0 \\
\hline $3 \quad 3 \frac{1}{2}$ & Plaice & 8 & $1 \cdot 6$ & $1 \cdot 1$ & 26 . & 0.8 & d \\
\hline 3 & 3 & 4 & $1 \cdot 4$ & $1 \cdot 2$ & $27 \cdot 2$ & -0.3 & poor \\
\hline 3 & Flounder & 5 & $1 \cdot 5$ & $1 \cdot 3$ & $28-$ & $-0 \cdot 2$ & \\
\hline $2 \frac{3}{4}$ & " & 8 & $1 \cdot 4$ & 1 & $24 \cdot 6-24 \cdot 6$ & 0 & I \\
\hline 4 & ", & - & - & - & - & - & - \\
\hline 4 & Plaic & - & - & - & - & - & - \\
\hline 3 & Flor & - & - & - & - & - & - \\
\hline $2 \frac{3}{4}$ & Plai & - & - & - & - & - & - \\
\hline 4 & Flout & - & - & - & - & - & - \\
\hline $2 \frac{1}{2}$ & " & - & - & - & 一 & - & - \\
\hline 3 & & - & - & - & - & 一 & - \\
\hline $3 \frac{1}{2}$ & aic & - & - & - & - & - & \\
\hline 4 & " & - & - & 二 & - & - & \\
\hline
\end{tabular}

No. of$$
\begin{gathered}
\text { Increas } \\
\text { in }
\end{gathered}
$$

May, 1916-October, 1916 $\begin{array}{cccc}\text { Length } & \text { in } \\ \text { in } \mathrm{cm}, & \begin{array}{c}\text { No. of } \\ \text { length. Condition. }\end{array} \text { sclerites. Max. Min. } & \begin{array}{l}\text { Length } \\ \text { in } \mathrm{cm} .\end{array} & \begin{array}{c}\text { in } \\ \text { length. Condition. }\end{array}\end{array}$

$$
\begin{aligned}
& \text { - - - } \\
& \text { - } \\
& \text { - - - } \\
& \text { - - - } \\
& \begin{array}{lllll}
11 & 1.5 & 1 & 28-28.3 & 0.3
\end{array} \\
& \begin{array}{llllll}
8 & 1 \cdot 3 & 1 & 29 \cdot 5-29 \cdot 6 & 0 \cdot 1 & \text { fair }
\end{array} \\
& \begin{array}{llllll}
12 & 1 \cdot 4 & 1 & 26 \cdot 2-26 \cdot 8 & 0 \cdot 6 & \text { good }
\end{array} \\
& \begin{array}{llllll}
9 & 1 \cdot 3 & 1 & 15 \cdot 5-15 \cdot 7 & 0 \cdot 2 & \text { fair }
\end{array} \\
& \begin{array}{llllll}
7 & 1 \cdot 2 & 1 & 32 \cdot 5-33 \cdot 5 & 1 & \text { good }
\end{array} \\
& \begin{array}{llllll}
10 & 1 \cdot 7 & 1 \cdot 1 & 17 \cdot 6-18 \cdot 4 & 0 \cdot 8 & \text { very good }
\end{array} \\
& \begin{array}{llllll}
9 & 1.4 & 1.1 & 25 \cdot 9-26 & 0.1 & \text { fair }
\end{array} \\
& \begin{array}{llllll}
10 & 1.4 & 1 & 29 \cdot 9-32.5 & 2 \cdot 6 & \text { very good }
\end{array} \\
& \begin{array}{llllll}
10 & 1.4 & 1 & 30 \cdot 5-30.9 & 0.4 & \text { fair }
\end{array} \\
& \begin{array}{l}
- \\
- \\
- \\
\text { - } \\
\text { good }
\end{array}
\end{aligned}
$$

\begin{tabular}{|c|c|c|c|c|c|c|c|c|c|c|c|c|c|c|c|c|}
\hline \multirow[b]{2}{*}{$\begin{array}{l}\text { Age } \\
\text { in } \\
\text { years. }\end{array}$} & \multicolumn{7}{|c|}{ July, 1915-January, 1916 Increase } & \multicolumn{8}{|c|}{ January, 1916-May, 1916} & \multirow[t]{2}{*}{$\mathrm{Ma}$} \\
\hline & & $\begin{array}{l}\text { No. of } \\
\text { clerites }\end{array}$ & & Min. & $\begin{array}{l}\text { Length } \\
\text { in em. }\end{array}$ & $\begin{array}{c}\text { Increast } \\
\text { in } \\
\text { length. }\end{array}$ & ondition. & $\begin{array}{l}\text { No. of } \\
\text { sclerites }\end{array}$ & 8. Max & Min. & $\begin{array}{l}\text { Length } \\
\text { in } \mathrm{cm} .\end{array}$ & $\begin{array}{c}\text { Increas } \\
\text { in } \\
\text { length }\end{array}$ & Condition. & $\begin{array}{l}\text { No. } \\
\text { scler }\end{array}$ & Ma: & \\
\hline 13 & Plaice & 9 & 1 & $\cdot 8$ & $24 \cdot 2-25$ & 0.8 & very good & 9 & 1 & $\cdot 8$ & $25-25 \cdot 5$ & 0.5 & good & - & - & \\
\hline 23 & & 4 & 1 & $\cdot 8$ & $8 \cdot 3$ & 0 & & 10 & $\cdot 9$ & $\cdot 7$ & $28 \cdot 3-28 \cdot 5$ & $0 \cdot 2$ & , & - & - & \\
\hline 33 & Flounder & 5 & 1 & $\cdot 9$ & $25 \cdot 5$ & $0 \cdot 3$ & good & - & - & - & - & - & - & 一 & - & \\
\hline $43 \frac{1}{2}$ & & 12 & 1 & $\cdot 8$ & $\cdot 5$ & $1 \cdot 7$ & excellent & - & - & - & - & - & - & 一 & - & \\
\hline $52 \frac{1}{2}$ & Plaice & 7 & 1 & $\cdot 8$ & 21 . & $0 \cdot 5$ & good & - & - & - & - & - & - & - & - & \\
\hline $\begin{array}{lll}6 & 4\end{array}$ & & 8 & 1 & $\cdot 9$ & & & & - & - & - & - & - & - & - & 一 & \\
\hline 73 & Flounder & ? & 1 & $\cdot 8$ & & & fai & 11 & $\cdot 9$ & $\cdot 6$ & 8 & $0 \cdot 4$ & very good & - & - & \\
\hline 84 & , & 8 & 1 & $\cdot 7$ & & $0 \cdot 7$ & gc & 10 & .9 & 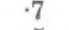 & & $0 \cdot 3$ & good & - & - & \\
\hline $3 \frac{1}{2}$ & & 1 & 1 & $\cdot 8$ & $28 \cdot 5$ & $1 \cdot 7$ & very good & 6 & .8 & .5 & 5 & 1 & ", & - & - & \\
\hline 3 & Plaice & - & - & - & - & - & - & 12 & .9 & $\cdot 6$ & 28. & 0.5 & & - & - & \\
\hline 4 & , & - & - & - & 一 & - & - & 9 & .8 & 7 & & $0 \cdot 1$ & fai & - & - & \\
\hline $2 \frac{3}{4}$ & , & - & - & - & - & - & - & & 5 & 0 & & $0 \cdot 4$ & $g_{0}$ & - & - & \\
\hline 2 & Floun & - & - & - & - & - & - & 10 & $\cdot 9$ & $\cdot 7$ & & $2 \cdot i$ & $\mathrm{~g}$ & 10 & & \\
\hline 3 & ," & - & - & - & 一 & - & - & 9 & $\cdot 9$ & $\cdot 7$ & & $0 \cdot 2$ & & 7 & $1 \cdot 1$ & \\
\hline 9 & & - & - & 一 & - & - & - & & $\cdot 9$ & $\cdot 7$ & & 0.4 & fai & 4 & 1 & \\
\hline 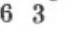 & & - & - & - & 一 & - & - & 9 & 1 & 7 & $25-25 \cdot 6$ & 0.6 & good & 6 & & \\
\hline
\end{tabular}

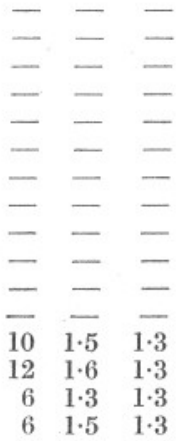$$
\text { - - - - }
$$

\section{TABLE IV}

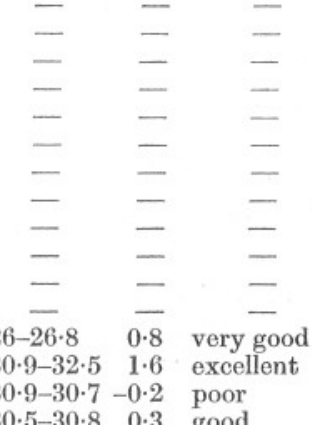

\section{Cold TANK}

January, 1916-May, 1916

Iay, 1916-October, 1916

$$
\text { Length increase }
$$

Length in
in $\mathrm{cm}$. length. Condition.

$$
\begin{array}{ccc}
- & - & - \\
- & - & - \\
- & - & - \\
- & - & - \\
- & - & - \\
- & - & - \\
- & - & - \\
- & - & - \\
21 \cdot 5-24 & 2 \cdot 5 & \text { very good } \\
24 \cdot 7-26 \cdot 2 & 1.5 & , " \\
20 \cdot 9-21 \cdot 2 & 0 \cdot 3 & \text { poor } \\
25 \cdot 6-26 \cdot 3 & 0.7 & \text { good }
\end{array}
$$


TABLE V

Abundant Tank

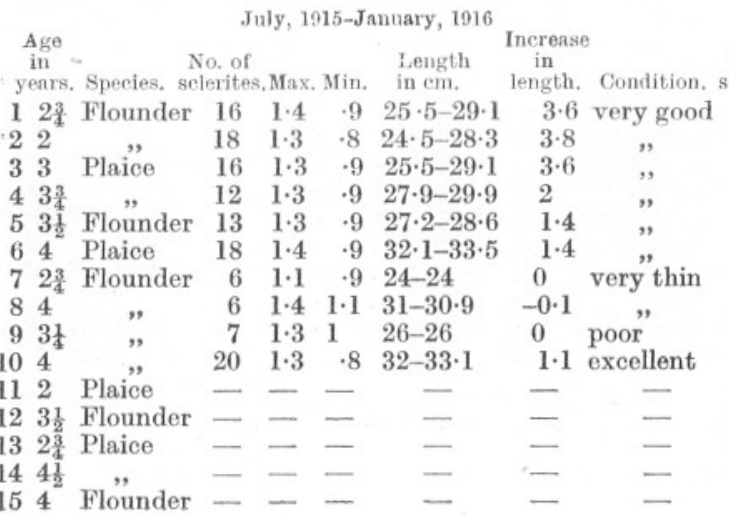

January, 1916-May, 1916

No. of
in
ength. Condition, selerites, Max. Min.

Length Increase

No. of
clerites. Max. Min.

in $\mathrm{cm}$.

Length
in $\mathrm{cm}$.
in

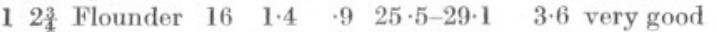

$\begin{array}{llll}- & - & - \\ 17 & 1 \cdot 2 & 7 \\ 12 & 1 & .7\end{array}$

$\begin{array}{llllll}12 & 1 & \cdot 7 & 29 \cdot 9-30 \cdot 6 & .7 & \text { very good }\end{array}$

$\begin{array}{llll}12 & 1 \cdot 1 & \cdot 8 & 28 \cdot 6-29\end{array}$

$\begin{array}{llll}19 & 1 \cdot 3 & \cdot 6 & 33 \cdot 5-34\end{array}$

$\begin{array}{llllll}11 & 1.5 & .9 & 24-24 \cdot 6 & .6 & \text { fair }\end{array}$

.5 excellent

$12 \quad \overline{1 \cdot 1} \quad \overline{8} \quad 33 \cdot \overline{-3} 3 \cdot 7 \quad \overline{6}$ excellent

$\begin{array}{llllll}13 & 1 \cdot 1 & 7 & 15 \cdot 2-16 \cdot 2 & 1 & \text { very good }\end{array}$

$\begin{array}{lllll}6 & 1 \cdot 3 & \cdot 8 & 26-27 \cdot 3 & 1 \cdot 3\end{array}$

$17 \cdot 5-17 \cdot 6 \cdot 1$ fair

$\begin{array}{llllll}7 & \cdot 9 & \cdot 7 & 17 \cdot 5-17 \cdot 6 & \cdot 1 & \text { fa } \\ 6 & 1 & \cdot 8 & 27-27 & 0 & ,\end{array}$

$\begin{array}{clllcl}6 & 1 & \cdot 8 & 27-27 & 0 & \text { " } \\ 18 & 1 \cdot 1 & \cdot 8 & 28 \cdot 3-29 \cdot 7 & 1 \cdot 4 & \text { excellent }\end{array}$

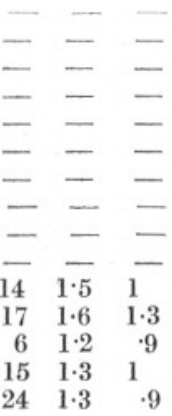

$\begin{array}{lll}\text { - } & - & - \\ - & - & - \\ - & - & - \\ \text { - } & - & - \\ - & - & - \\ - & - & -\end{array}$

$16 \cdot 2-18 \quad \overline{18}$ excellent $27 \cdot 3-29 \quad 1 \cdot 7$

\section{TABLE VI}

Scanty Tank

July, 1915-January, 1916

January, 1916-May, 1916 $17 \cdot 6-18 \cdot 5 \cdot 0 \cdot 9$ very thin $27-29 \cdot 1 \quad 2 \cdot 1 \quad$ very good $29 \cdot 7-33 \cdot 2 \quad 3 \cdot 5$ excellent

\begin{tabular}{|c|c|c|c|c|c|c|c|c|c|c|c|c|}
\hline $\begin{array}{c}\text { Age } \\
\text { in } \\
\text { years. }\end{array}$ & Species. sc & $\begin{array}{l}\text { No. of } \\
\text { clerites }\end{array}$ & S. Max & Min. & $\begin{array}{r}\text { Length } \\
\text { in } \mathrm{cm} .\end{array}$ & $\begin{array}{c}\text { Increas } \\
\text { in } \\
\text { length. }\end{array}$ & Condition. & $\begin{array}{l}\text { No. o } \\
\text { sclerit }\end{array}$ & f & Min. & $\begin{array}{l}\text { Length } \\
\text { in } \mathrm{cm} .\end{array}$ & $\begin{array}{r}\text { Incre: } \\
\text { in } \\
\text { leng }\end{array}$ \\
\hline $14 \frac{3}{4}$ & Flounder & 6 & $1 \cdot 3$ & $1 \cdot 1$ & $31 \cdot 5-31 \cdot 5$ & 0 & very thin & - & - & - & - & \\
\hline $23 \frac{3}{4}$ & , & 8 & $1 \cdot 3$ & 0.6 & $28 \cdot 5-28 \cdot 6$ & $0 \cdot 1$ & & - & - & - & - & \\
\hline $32 \frac{3}{4}$ & , & 10 & $1 \cdot 3$ & $0 \cdot 8$ & $20 \cdot 2-22 \cdot 4$ & $2 \cdot 2$ & good & 8 & $1 \cdot 1$ & $0 \cdot 7$ & $22 \cdot 4-23$ & $\cdot 6$ \\
\hline $44 \frac{1}{2}$ & Plaice & 6 & $1 \cdot 2$ & $0 \cdot 9$ & $33 \cdot 5-34$ & 0.5 & fair & 8 & 1 & 0.8 & $34-34 \cdot 2$ & $\cdot 2$ \\
\hline 53 & & 8 & $1 \cdot 2$ & 0.9 & $21 \cdot 3-21 \cdot 5$ & $0 \cdot 2$ & ", & 8 & $1 \cdot 1$ & $0 \cdot 7$ & $21 \cdot 5-21 \cdot 8$ & $\cdot 3$ \\
\hline $63 \frac{3}{4}$ & Flounder & 8 & $1 \cdot 2$ & $0 \cdot 8$ & $26-26 \cdot 6$ & $0 \cdot 6$ & " & 8 & 1 & $0 \cdot 6$ & $26 \cdot 6-26 \cdot 9$ & $\cdot 3$ \\
\hline $74 \frac{1}{2}$ & ", & 10 & $1 \cdot 4$ & 0.9 & $30 \cdot 5-31 \cdot 3$ & $0 \cdot 8$ & good & - & - & - & - & \\
\hline $82 \frac{3}{4}$ & , & 5 & $1 \cdot 3$ & 0.7 & $24 \cdot 9-24 \cdot 9$ & 0 & very thin & - & - & - & - & \\
\hline 94 & ", & 4 & $1 \cdot 2$ & 0.5 & $30-29 \cdot 9$ & $-0 \cdot 1$ & , & - & - & - & - & - \\
\hline 102 & , & 8 & $1 \cdot 3$ & $0 \cdot 6$ & $20 \cdot 5-20 \cdot 6$ & $0 \cdot 1$ & , & - & - & - & - & \\
\hline - & - & - & - & 一 & - & - & 一 & 7 & $0 \cdot 9$ & $0 \cdot 6$ & $33 \cdot 5-33 \cdot 6$ & . \\
\hline - & - & - & - & - & - & - & - & 10 & 0.9 & $0 \cdot 7$ & $24 \cdot 6-25$ & $0 \cdot 4$ \\
\hline - & - & - & 一 & - & - & 一 & - & 10 & 1 & 0.6 & $30 \cdot 5-31$ & $0 \cdot 5$ \\
\hline $4-$ & - & - & - & - & - & - & - & 9 & 0.9 & $0 \cdot 7$ & $13 \cdot 5-13 \cdot 7$ & 0.2 \\
\hline 一 & - & - & - & - & - & - & - & 8 & 1 & 0.8 & $21 \cdot 3-21 \cdot 5$ & 0.6 \\
\hline
\end{tabular}

May, 1916-October, 1916

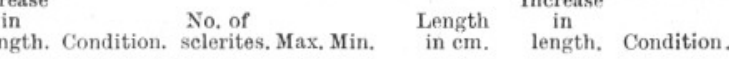

\begin{tabular}{|c|c|c|c|c|c|c|}
\hline - & - & 一 & - & - & - & - \\
\hline- & - & - & - & - & - & - \\
\hline fair & - & - & - & - & - & - \\
\hline ", & - & 一 & 一 & 一 & - & - \\
\hline , & - & - & - & - & - & - \\
\hline " & - & - & - & - & - & - \\
\hline & - & - & - & - & - & - \\
\hline- & - & - & - & - & - & - \\
\hline - & - & - & - & - & - & - \\
\hline fair & 5 & 0.8 & $0 \cdot 8$ & $33 \cdot 6-34$ & 0.4 & very poor \\
\hline good & 8 & $1 \cdot 1$ & $0 \cdot 9$ & $25-25 \cdot 5$ & 0.5 & fair \\
\hline$"$ & 7 & $1 \cdot 2$ & 1 & $32-32 \cdot 9$ & $0 \cdot 9$ & good \\
\hline & 12 & $1 \cdot 3$ & 1 & $13 \cdot 7-16$ & $2 \cdot 3$ & very good \\
\hline iir & 9 & 1.2 & 0.9 & $21 \cdot 5-22 \cdot 5$ & 1.5 & good \\
\hline
\end{tabular}

